\title{
Chronic Sulforaphane Application Does Not Induce Resistance in Renal Cell Carcinoma Cells
}

\author{
JOCHEN RUTZ $^{1}$, EVA JUENGEL ${ }^{1,2}$, STEPHANIE EULER ${ }^{1}$, SEBASTIAN MAXEINER ${ }^{1}$, \\ SAIRA JUSTIN $^{1}$, FREDERIK ROOS ${ }^{1}$, FELIX K.-H. CHUN ${ }^{1}$ and ROMAN A. BLAHETA ${ }^{1}$ \\ ${ }^{1}$ Department of Urology, Goethe-University, Frankfurt am Main, Germany; \\ ${ }^{2}$ Department of Urology and Pediatric Urology, University Medical Center Mainz, Mainz, Germany
}

\begin{abstract}
Background/Aim: Since the natural compound sulforaphane (SFN) has been shown to stop tumor growth, renal cell carcinoma (RCC) patients often use this drug in addition to their prescribed oncotherapy. The aim of this study was to examine whether resistance to SFN may develop after long-term application. Materials and Methods: Several RCC cell lines were incubated with SFN for short periods of time (24-72 h) or long periods of time ( 8 weeks) and cell growth, proliferation, and cell-cycle proteins were analyzed. Results: Both short- and long-term application of SFN distinctly reduced RCC cell growth and proliferation. However, differences in the distribution of cells in each phase of the cell cycle and in the expression of cell-cycle proteins were apparent. Short-term treatment induced $S$ phase arrest, whereas long-term treatment induced $G_{0} / G_{I^{-}}$ phase arrest. Expression of Cdk1 and Cdk2 increased over short-term incubation, but decreased long-term. Expression of $p C d k 2, A k t$, and Raptor were reduced following long-term $S F N$-exposure, but remained unchanged when SFN was applied for short periods of time. Conclusion: Chronic use of SFN did not evoke resistance, but differentially altered signaling pathways, compared to short-term use.
\end{abstract}

Renal cell carcinoma (RCC) accounts for 3\% of all malignant neoplasms in adults, and its incidence is increasing (1). Almost $30 \%$ of patients have metastases at diagnosis, and more than two-thirds of patients with localized disease relapse within 5 years (2), at which time point palliative therapy remains the only option. RCC does not satisfactorily respond to

Correspondence to: Prof. Dr. phil. nat. Roman A. Blaheta, Department of Urology, Interdisciplinary Science Building, GoetheUniversity, Building 25A, Room 404, Theodor-Stern-Kai 7, D60590 Frankfurt/Main, Germany. Tel: +49 6963017109, Fax: +49 6963017108, e-mail: blaheta@em.uni-frankfurt.de

Key Words: Sulforaphane, renal cell carcinoma, resistance, cell cycling, cell proliferation. chemotherapy or radiotherapy (3), and interleukin 2 or interferon-alpha-based immunotherapy induces a weak response rate of only $10-15 \%(4,5)$. Novel licensed target drugs, including the tyrosine kinase inhibitors sunitinib and sorafenib and the mechanistic target of rapamycin (mTOR) inhibitors temsirolimus and everolimus, have significantly improved patient outcome, but resistance still develops during chronic treatment (6).

Dissatisfaction with conventional tumor treatment and the wish to actively contribute to tumor therapy are the main reasons why cancer patients seek complementary or alternative (CAM) medicinal options. The number of cancer patients using CAM ranges from $18-51 \%(7,8)$, whereby natural herb treatment is the most prominent. About $30 \%$ of CAM users in Germany and Italy favor phytotherapeutic agents $(9,10)$, and in Canada and Northern USA use exceeds $60 \%(11,12)$.

Due to the high content of glucosinolates, whose breakdown product sulforaphane (SFN) has been shown to possess chemopreventive properties (13), the dietary consumption of cruciferous vegetables (broccoli (Brassica oleracea var. italic), cabbage (Brassica oleracea var. capitata), radish (Raphanus sativus), kale (Brassica oleracea var. acephala) and cauliflower (Brassica oleracea var. botryitis)) has become very popular among CAM-users. After enzymatic hydrolysis of the glucosinolates by myrosinase, SFN becomes available. In vitro and in vivo studies point to significant anti-inflammatory and anticarcinogenic properties of SFN by regulating intracellular pathways involved in tumor initiation, promotion, progression, and metastasis. Consuming one serving of raw broccoli per month (average intake 3.9 servings/month) has been shown to reduce disease-specific and overall mortality of bladder cancer patients (14). Cipolla et al., employed an oral dose of $60 \mathrm{mg} /$ day SFN in the treatment of prostate cancer patients (15). SFN might, therefore, be a promising agent to prevent or delay cancer development in various organs. However, it is not clear whether long-term use of SFN may evoke resistance mechanisms leading to nonresponsiveness and aggressive tumor re-growth, as occurs 
with many other oncotherapeutic drugs. Therefore, the growth and proliferation of RCC cell lines after application of SFN was investigated to evaluate of its effects following short- and long-term treatment.

\section{Materials and Methods}

Cell culture. Renal carcinoma A498, Caki1, and KTCTL-26 cell lines were purchased from LGC Promochem (Wesel, Germany). The tumor cells were grown and subcultured in RPMI 1640 medium (Gibco/Invitrogen, Karlsruhe, Germany) supplemented with $10 \%$ fetal calf serum (FCS), 2\% Hepes buffer, 1\% Glutamax, and 1\% penicillin/streptomycin at $37^{\circ} \mathrm{C}$ in a humidified $5 \% \mathrm{CO}_{2}$ incubator.

Drug treatment. SFN (4-methylsulfinybutyl isothiocyanate, Figure 1) purchased from Biomol, (Hamburg, Germany), was stored at $-20^{\circ} \mathrm{C}$ and was diluted in cell culture medium to a final concentration of 5 $\mu \mathrm{M}$ prior to use. Control cell cultures received cell culture medium without SFN. To exclude toxic effects of the compound, cell viability was determined by trypan blue (Gibco/Invitrogen).

Tumor cells were subjected to the experimental protocols either shortly after SFN-treatment (24-72 h incubation; short-term) or after treatment with SFN for eight weeks (long-term). Medium was changed thrice weekly. Before experimentation, cell culture medium of the longterm treated cells containing $5 \mu \mathrm{M}$ SFN was replaced by SFN-free medium for three days. After this wash-out phase, tumor cells were retreated with SFN for 24-72 $\mathrm{h}$ and tumor cell growth and proliferation were assayed. Medium was also changed for the control cells.

Measurement of tumor cell growth and proliferation. Cell growth was evaluated using the 3-(4,5-dimethylthiazol-2-yl)-2,5diphenyltetrazolium bromide (MTT) dye reduction assay (Roche Diagnostics, Penzberg, Germany). Tumor cells (100 $\mu 1,5 \times 10^{4}$ cells $/ \mathrm{ml}$ ) were plated into 96-well tissue culture plates. After 24,48 , and $72 \mathrm{~h}$, MTT $(0.5 \mathrm{mg} / \mathrm{ml})$ was added for an additional $4 \mathrm{~h}$. The reaction was stopped by lysing the cells in a buffer containing $10 \%$ SDS in $0.01 \mathrm{M} \mathrm{HCl}$. After incubating the plates at $37^{\circ} \mathrm{C}$, in a humidified $5 \% \mathrm{CO}_{2}$ incubator overnight, the absorbance at $570 \mathrm{~nm}$ was measured using a microplate ELISA reader. Each experiment was done in triplicate. After subtracting background absorbance, results were expressed as mean cell number.

Cell proliferation was measured using a BrdU cell proliferation enzyme-linked immunosorbent assay (ELISA) kit (Calbiochem/ Merck Biosciences, Darmstadt, Germany). SFN-treated and nontreated tumor cells were seeded onto 96-well tissue culture plates, incubated with $20 \mu \mathrm{BrdU}$-labelling solution per well for $8 \mathrm{~h}$, fixed and detected using anti-BrdU mAb according to the manufacturer's instructions. Absorbance was measured at $450 \mathrm{~nm}$ after $24 \mathrm{~h}$.

Cell cycle analysis. Cell-cycle analysis was carried out with sub confluent tumor cells (treated versus non-treated). Tumor cell populations were stained with propidium iodide, using a Cycle TEST PLUS DNA Reagent Kit (BD Biosciences, Heidelberg, Germany) and then subjected to flow cytometry with a FACScan flow cytometer (Becton Dickinson, Heidelberg, Germany) after $24 \mathrm{~h}$ of cultivation. 10,000 events were collected for each sample. Data acquisition was carried out using Cell-Quest software and cell cycle distribution was calculated using the ModFit software (BD Biosciences). The number of gated cells in the $\mathrm{G}_{1}, \mathrm{G}_{2} / \mathrm{M}$, or S-phase was presented as $\%$.

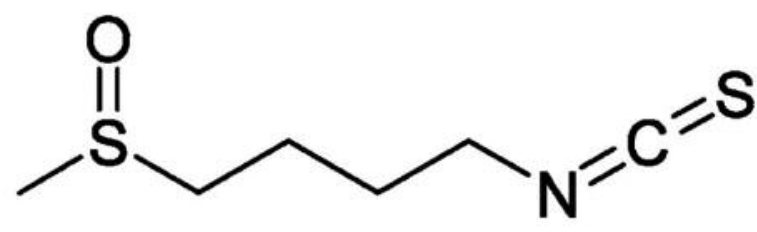

Figure 1. Structural formula of SFN (47).

Western blot analysis. Cell cycle regulating protein levels were investigated in Cakil cells. Tumor cell lysates were applied to $7 \%$ to $12 \%$ polyacrylamide gel and electrophoresed for 90 minutes at $100 \mathrm{~V}$. The proteins were then transferred to nitrocellulose membranes $(1 \mathrm{~h}$, $100 \mathrm{~V})$. After blocking with nonfat dry milk for $1 \mathrm{~h}$, the membranes were incubated overnight with monoclonal antibodies directed against the cell cycle proteins: Cdk1 (IgG1, clone 1), pCdk1/Cdc2 (IgG1, clone 44/Cdk1/Cdc2 (pY15)), Cdk2 (IgG2a, clone 55), Cyclin A (IgG1, clone 25), Cyclin B (IgG1, clone 18; all: BD Biosciences), and pCdk2 (Thr160; Cell Signaling, Frankfurt, Germany). The mechanistic target of rapamycin (mTOR) pathway was investigated by using the following monoclonal antibodies: Raptor (24C12; Cell Signaling), anti phospho Raptor (pRaptor; IgG, Ser792; New England Biolabs, Frankfurt, Germany), PKB $\alpha /$ Akt (IgG1 clone 55), anti phospho Akt (pAkt; IgG1, Ser472/Ser473, clone 104A282; BD Pharmingen). HRP-conjugated goat anti-mouse IgG and HRPconjugated goat anti-rabbit IgG (1:5,000; Upstate Biotechnology, Lake Placid, NY, USA) served as the secondary antibody. The membranes were briefly incubated with ECL detection reagent (ECL; Amersham/GE Healthcare, München, Germany) to visualize the proteins and then analyzed by the Fusion FX7 system (Peqlab, Erlangen, Germany). $\beta$-Actin (1:1,000; clone AC-15; Sigma-Aldrich, Taufenkirchen, Germany) served as the internal control. Gimp 2.8 software was used to perform pixel density analysis of the protein bands and to calculate the ratio of protein intensity/ $\beta$-actin intensity.

Statistics. All experiments were performed three to six times. Statistical significance was calculated with the Wilcoxon-MannWhitney $U$-test. Differences were considered statistically significant at a $p$-value less than 0.05 .

\section{Results}

Tumor cell growth. Short-term treatment with SFN caused a significant growth reduction in all three RCC cell lines, compared to the controls (Figure 2A) and long-term treatment induced an even stronger growth blockade. The trypan blue test revealed no toxic effects of the compound so that growth suppression cannot be attributed to necrosis.

Tumor cell proliferation. Tumor cell proliferation of all three cell lines significantly decreased following short-term SFN exposure (Figure 2B). Long-term application induced an even further decrease in proliferation of A498 cells, compared to short-term treatment, whereas no differences between short- and long-term application were seen in Caki1 and KTCTL-26 cells. 
A

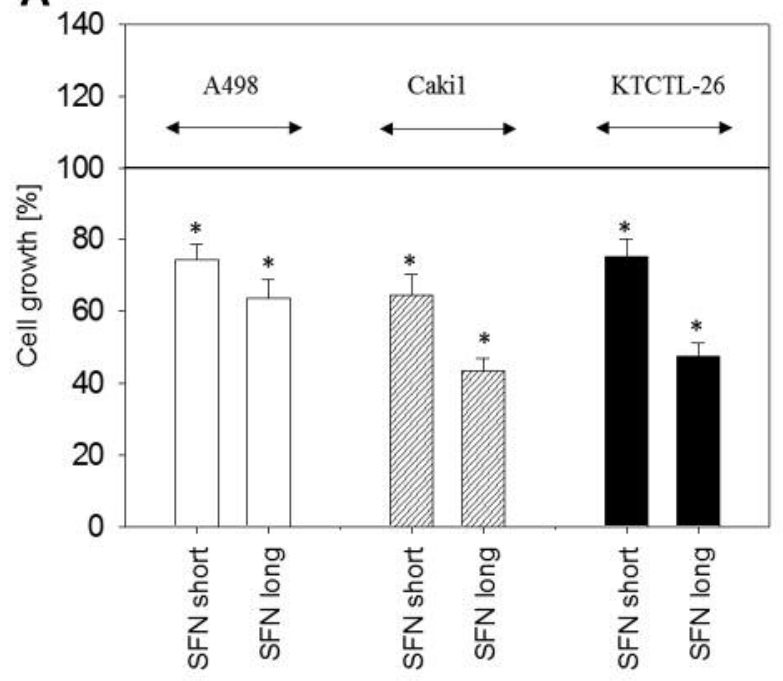

B

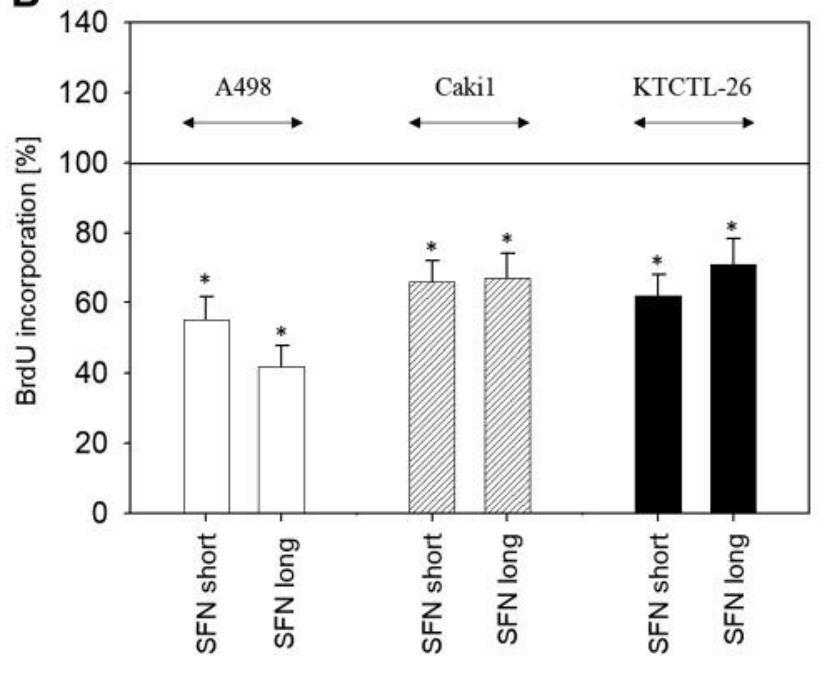

Figure 2. A: Growth of A498, Caki1, and KTCTL-26 RCC cells treated short-and long-term with $5 \mu M$ SFN. Percentage difference from 24 h, control (100\%), to $72 \mathrm{~h}$ is shown. Each experiment was performed in triplicate and repeated 5 times. *Indicates significant difference from controls. B: Cell proliferation of A498, Cakil and KTCTL-26 cells treated short-and long-term with $5 \mu M$ SFN. BrdU incorporation is shown as percentage difference to the untreated control. Each experiment was performed in triplicate and repeated 5 times. *Indicates significant difference to controls set to $100 \%$.

Cell cycle progression. Cell cycle progression was analyzed for A498 and Caki1 cells. SFN short-term exposure was associated with an increase in the S-phase along with a decrease of $\mathrm{G}_{0} / \mathrm{G}_{1}$-phase cells, compared to controls (Figure 3A). In A498 cells an additional reduction in $\mathrm{G}_{2} / \mathrm{M}$-phase cells was also apparent. In contrast, upon long-term treatment with SFN the number of A498 and Caki1 cells in the $G_{0} / G_{1}$ phase increased, whereas the number of S-phase cells decreased. Since similar effects were seen on A498 and Caki1 cells, the subsequent study was restricted to the Cakil cell line.

Western blot analysis. Short-term SFN exposure was accompanied by a significant up-regulation of Cdk1 (both total and activated), $\mathrm{Cdk} 2$ and cyclin $\mathrm{A}$, whereas Cyclin B, pAkt and pRaptor were down-regulated (Figure 3B). In contrast, long-term SFN application down-regulated Cdk1, Cdk2, and pCdk2. Akt and Raptor were diminished, while Cyclin B was not influenced following long-term treatment. Similar to short-term SFN application pCdk1 and Cyclin A were enhanced, while pAkt and pRaptor were suppressed, each compared to respective controls.

\section{Discussion}

SFN has been widely used to treat inflammatory disease, and recent studies attest to an anti-tumor effect in vitro and in vivo $(16,17)$. In the present study both long- and short-term administration of SFN suppressed the growth of all three
RCC cell lines tested, without inducing resistance. However, the growth inhibition was associated with different cellular mechanisms, depending on whether SFN was applied shortor long-term.

The SFN concentration used in studies that have shown inhibition of progressive behavior of several cancer entities range between 5-20 $\mu \mathrm{M}(18,19)$. Prior dose-responseanalyses done on Caki1, A498, and KTCTL-26 have demonstrated that 1.25 or $2.5 \mu \mathrm{M}$ SFN are sufficient to evoke anti-tumor effects (20). In the present investigation $5 \mu \mathrm{M}$ $\mathrm{SFN}$ was employed, since the $\mathrm{IC}_{50}$ was calculated to be near this concentration.

During short-term application, $5 \mu \mathrm{M}$ SFN elevated the number of Caki-1 and A498 cells in the S-phase of cell cycle and reduced the number cells in the $G_{0} / G_{1}$-phase. This is in accordance with a previous study, where SFN induced an increase in the number of Caki1 tumor cells in the S-phase (21). Interestingly, the number of cells found in the $G_{2} / M$-phase instead of S-phase has been found to increase when Caki1 were synchronized at the $\mathrm{G}_{1} / \mathrm{S}$ transition and then subjected to $5 \mu \mathrm{M}$ SFN (21). Cakil cells were also found to accumulate at both $\mathrm{S}$ and $\mathrm{G}_{2} / \mathrm{M}$-phase when treated with $20 \mu \mathrm{M}$ SFN (20). A dosedependent alteration in cell cycling has also been observed by others (22). Herman-Antosiewicz point to a switch from S$/ \mathrm{G}_{2} / \mathrm{M}$-phase elevation to a $\mathrm{G}_{0} / \mathrm{G}_{1}$-phase elevation with increasing SFN concentrations in prostate cancer cells (23). Experiments on osteosarcoma cells have shown that SFN induces a $\mathrm{G}_{2} / \mathrm{M}$-phase block at concentrations $\leq 10 \mu \mathrm{M}$, but an 
A

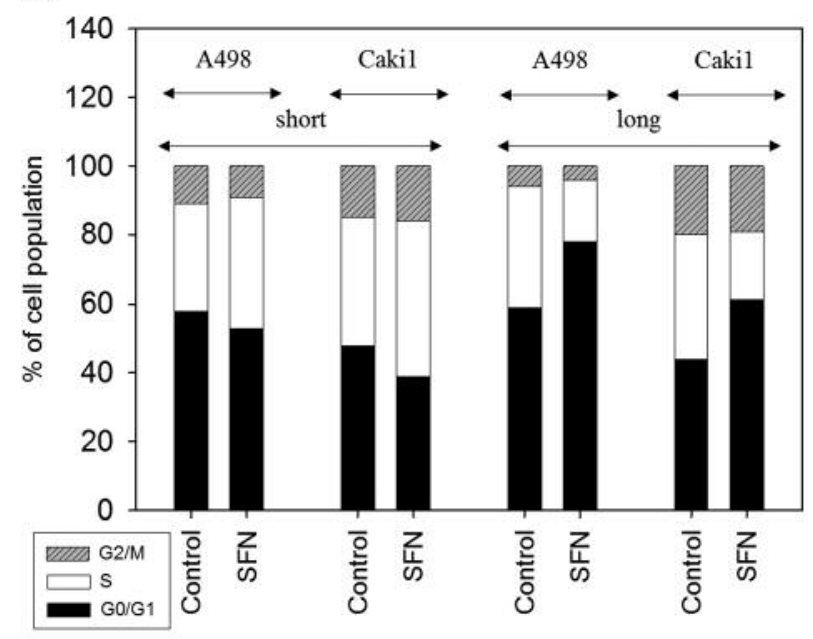

B

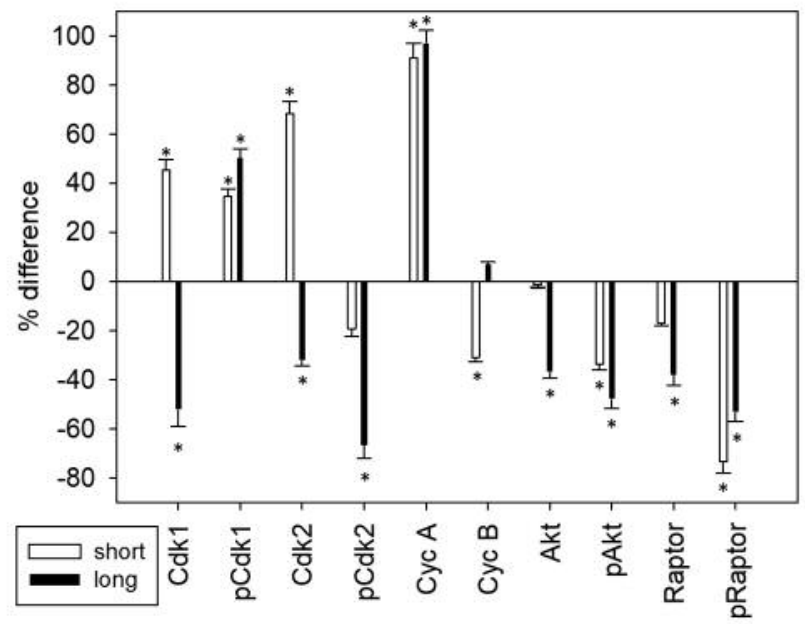

Figure 3. A: Cell-cycle analysis of A498, Caki1, and KTCTL-26 cells. Subconfluent cell cultures were treated with $5 \mu M$ SFN for 24 h("short") or for 8 weeks ("long") and cell-cycle phases evaluated by flow cytometry. Controls were untreated. Tumor cell populations in $G_{0} / G_{1}, S$ - and $G_{2} / M$ phase are shown as percentage of total analyzed cells. One representative experiment of three is shown. B: Pixel density values of cell cycle and mTOR related proteins, evaluated by western blotting. Cakil cells were pre-treated with SFN for 24 h (short) or 8 weeks (long). Controls remained untreated. Each experiment was repeated 5 times. Values are given as percentage difference to untreated controls. *Indicates significant difference to controls, set to 0 .

S-phase and $\mathrm{G}_{2} / \mathrm{M}$-phase block at concentrations $>10 \mu \mathrm{M}(24)$. In the present in vitro model, short-term treatment with $5 \mu \mathrm{M}$ SFN was shown to induce accumulation of Caki-1 and A498 cells in the S-phase. Therefore, SFN's molecular mode of action may (at least partially) depend on the cell cycle status and on the SFN-concentration used.

Administration of SFN over 8 weeks induced distinct suppression of RCC growth and proliferation, as did short-term administration. An 8-week drug incubation has earlier been shown adequate in inducing resistance towards the TKI sunitinib and the mTOR inhibitor everolimus in RCC cells (25, 26). Since SFN maintained its tumor-suppressive properties over an 8-week incubation, it is apparent that resistance development does not occur with this substance during a time period in which other oncotherapeutics do induce resistance. From a clinical perspective this is important since resistance is a primary factor leading to treatment failure. If SFN does not induce resistance in vivo (still to be proven by animal studies), it might be considered a valuable adjunctive to accompany the present RCC treatment regimen based on TKIs and/or mTOR inhibitors. Long term application of gemcitabine or SFN for 1 year to pancreatic cancer cells led to resistance development towards gemcitabine but not to SFN (27), which is in line with our observation. Besides in vivo investigations, which should be done, ongoing studies on a panel of different tumor entities are required to investigate whether the long-term inhibitory effects of SFN observed on growth and proliferation of RCC cells extend to further tumor types.
Cell cycle analysis of both A498 and Caki-1 cells revealed an inverse regulation of cell cycling under long-term SFN application, compared to short-term. However, SFN's biological action to inhibit growth and proliferation is similar over both time periods, even though the molecular mechanism differs. Indeed, Pappa et al., observed a timeindependent suppression of colon cancer cell growth by SFN, accompanied by a time-dependent switch from $\mathrm{G}_{2} / \mathrm{M}$ phase to a $\mathrm{G}_{1}$-phase block (28). Lubelska et al. and NegretteGuzmán et al. assumed from their studies that SFN's effects might depend on the tumor cell differentiation status (29, 30). Hudecova et al. reported that epigenetic activation /deactivation of cell signaling proteins in carcinoma cells closely depends on the SFN incubation time period (31). Similarly, NF-kappa B - DNA binding, was found to be reduced early after adding SFN ( $<24 \mathrm{~h}$ incubation), but enhanced following prolonged incubation ( $>24 \mathrm{~h}$ ) (32). These investigators did not evaluate cell cycling under SFN.

The cell cycle switch correlated with a switch in cell cycle regulating protein expression. This was particularly true for $\mathrm{Cdk} 1$ and Cdk2, which were up-regulated short-term but downregulated under long-term SFN-treatment. Sufficient evidence has been provided that $\mathrm{Cdk} 2$ along with Cyclin $\mathrm{A}$ forces cells to transit from the $G_{1}$ into the S-phase $(33,34)$. The Cdk1Cyclin B-complex regulates $G_{1} / S$ transition (35), but is also relevant in the late S-phase to control cell progression into $\mathrm{G}_{2} / \mathrm{M}(33,34)$. Fung and coworkers observed elevated Cyclin A in tumor cells arrested in the S-phase and elevated Cyclin B 
and $\mathrm{Cdk} 1$ in tumor cells arrested in $\mathrm{G}_{2} / \mathrm{M}$ (36). In a similar fashion, cell cycle block at the $S$ and $G_{2} / M$ checkpoints correlated with an up-regulation of cyclin A and cyclin B1 and sustained phosphorylation of Cdk1 (37). Therefore, SFN seems to cause Cdk1 and Cdk2 up-regulation in the early phase of cell treatment, leading to an S-phase arrest. Still, the roles of these proteins and the interacting proteins Cyclin B and A are not fully understood and require further investigation. Findings in this regard do not coincide with reports from previous studies. At this point it is not possible to explain why activation of Cdk2 was not altered and why Cyclin B was diminished under short-term SFN exposure.

Loss of Cdk1 and 2 under long-term SFN treatment correlated with a $G_{0} / G_{1}$ phase block as has also been found by others (38-40). Presumably, a functional switch of SFN during long-term exposure takes place, such that the diminished $\mathrm{Cdk} 1$ and 2 expression level drives the tumor cells into $\mathrm{G}_{0} / \mathrm{G}_{1}$. The expression level of Akt and Raptor (total) also depended on the SFN incubation time (being significantly reduced under long-term SFN treatment but uninfluenced under short-term application). The crosscommunication between Akt-mTOR and the Cdk-axis is well documented. In good accordance to our results, Cdk2 downregulation has been shown to be associated with Akt suppression and $\mathrm{G}_{0} / \mathrm{G}_{1}$-phase arrest $(41,42)$, whereas $\mathrm{Cdk} 2$ up-regulation correlated with Akt elevation and S-phase arrest (43). Although enhanced Akt expression levels were not observed, Cdk2 elevation was also accompanied by an increased number of S-phase cells in our study. Nevertheless, since Cdk2 but not Akt and Raptor were enhanced by SFN, and since phosphorylation of Akt and Raptor was diminished irrespective of the Cdk2 expression levels, Akt-mTOR signaling may modulate tumor cell growth independently from Cdk2. In fact, Akt phosphorylation can be altered independently from Cdk2 (44). Vice versa, Cdk2 can mediate cell proliferation independently from Akt signaling (45). An interesting aspect has been presented by Maddika et al. who provided evidence that Akt may differentially regulate cell cycling, dependent on the duration of Akt phosphorylation (46). Speculatively, short-term Akt (and Raptor) dephosphorylation (seen under short-term SFN exposure) may trigger Cdk2 elevation, whereas long-term Akt (and Raptor) de-phosphorylation (seen under long-term SFN exposure) may induce a mechanistic switch towards $\mathrm{Cdk} 2$ suppression. This may also hold true for Cdk1, but since no data are currently available, this remains speculative.

In conclusion, evidence is presented that SFN inhibits growth and proliferation of RCC cells in vitro and that longterm administration does not cause resistance, making SFN a candidate for clinical application. Since SFN maintains long-term antitumor properties without resistance development, comparing the molecular mechanisms of this substance with those of drugs that do induce resistance may offer insights into molecular mechanisms leading to resistance. The switch in SFN's molecular mode of action concerning Cdk1 and Cdk2 during short- and long-term exposure deserves particular attention.

\section{Conflicts of Interest}

The Authors have no conflicts of interest to disclose.

\section{References}

1 Maute L, Grünwald V, Weikert S, Kube U, Gauler T, Kahl C, Burkholder I and Bergmann L: Therapy of mRCC beyond mTOR-inhibition in clinical practice: results of a retrospective analysis. J Cancer Res Clin Oncol 140: 823-827, 2014.

2 Kroeger N, Choueiri TK, Lee JL, Bjarnason GA, Knox JJ, MacKenzie MJ, Wood L, Srinivas S, Vaishamayan UN, Rha SY, Pal SK, Yuasa T, Donskov F, Agarwal N, Tan MH, Bamias A, Kollmannsberger CK, North SA, Rini BI and Heng DY: Survival outcome and treatment response of patients with late relapse from renal cell carcinoma in the era of targeted therapy. Eur Urol 65: 1086-1092, 2014.

3 Walsh N, Larkin A, Kennedy S, Connolly L, Ballot J, Ooi W, Gullo G, Crown J, Clynes M and O'Driscoll L: Expression of multidrug resistance markers ABCB1 (MDR-1/P-gp) and ABCC1 (MRP-1) in renal cell carcinoma. BMC Urol 9: 6, 2009.

4 Negrier S, Perol D, Ravaud A, Chevreau C, Bay JO, Delva R, Sevin E, Caty A and Escudier B; French Immunotherapy Intergroup: Medroxyprogesterone, interferon alfa-2a, interleukin 2 , or combination of both cytokines in patients with metastatic renal carcinoma of intermediate prognosis: results of a randomized controlled trial. Cancer 110: 2468-2477, 2007.

5 Fosså SD: Interferon in metastatic renal cell carcinoma. Semin Oncol 27: 187-193, 2000.

6 Han KS, Raven PA, Frees S, Gust K, Fazli L, Ettinger S, Hong SJ, Kollmannsberger C, Gleave ME and So AI: Cellular adaptation to VEGF-targeted antiangiogenic therapy induces evasive resistance by overproduction of alternative endothelial cell growth factors in renal cell carcinoma. Neoplasia 17: 805$816,2015$.

7 König J, Geschwill K, Lang A, Tauchert FK, Hofheinz RD and Kripp M: Use of complementary and alternative medicine in cancer patients: a prospective questionnaire-based study in an oncological outpatient clinic. Oncol Res Treat 39: 260-265, 2016.

8. Wortmann JK, Bremer A, Eich HT, Wortmann HP, Schuster A, Fühner J, Büntzel J, Muecke R, Prott FJ and Huebner J: Use of complementary and alternative medicine by patients with cancer: a cross-sectional study at different points of cancer care. Med Oncol 33: 78, 2016.

9 Hierl M, Pfirstinger J, Andreesen R, Holler E, Mayer S, Wolff $\mathrm{D}$ and Vogelhuber M: Complementary and alternative medicine: a clinical study in 1,016 hematology/oncology patients. Oncology 93: 157-163, 2017.

10 Saini A, Berruti A, Capogna S, Negro M, Sguazzotti E, Picci RL, Campagna S, Dongiovanni V, Dogliotti L, Furlan PM and Ostacoli L: Prevalence of complementary/alternative medicines (CAMs) in a cancer population in northern Italy receiving antineoplastic treatments and relationship with quality of life and psychometric features. Qual Life Res 20: 683-690, 2011. 
11 Schieman C, Rudmik LR, Dixon E, Sutherland F and Bathe OF: Complementary and alternative medicine use among general surgery, hepatobiliary surgery and surgical oncology patients. Can J Surg 52: 422-426, 2009.

12 Miller MC, Pribitkin EA, Difabio T and Keane WM: Prevalence of complementary and alternative medicine use among a population of head and neck cancer patients: a survey-based study. Ear Nose Throat J 89: E23-E27, 2010.

13 Briones-Herrera A, Eugenio-Pérez D, Reyes-Ocampo JG, Rivera-Mancía S and Pedraza-Chaverri J: New highlights on the health-improving effects of sulforaphane. Food Funct 9: 25892606, 2018.

14 Tang L, Zirpoli GR, Guru K, Moysich KB, Zhang Y, Ambrosone $\mathrm{CB}$ and McCann SE: Intake of cruciferous vegetables modifies bladder cancer survival. Cancer Epidemiol Biomarkers Prev 19: 1806-1811, 2010.

15 Cipolla BG, Mandron E, Lefort JM, Coadou Y, Della Negra E, Corbel L, Le Scodan R, Azzouzi AR and Mottet N: Effect of sulforaphane in men with biochemical recurrence after radical prostatectomy. Cancer Prev Res (Phila) 8: 712-719, 2015.

16 Dang YM, Huang G, Chen YR, Dang ZF, Chen C, Liu FL, Guo YF and Xie XD: Sulforaphane inhibits the proliferation of the BIU87 bladder cancer cell line via IGFBP-3 elevation. Asian Pac J Cancer Prev 15: 1517-1520, 2014.

17 Bergantin E, Quarta C, Nanni C, Fanti S, Pession A, CantelliForti G, Tonelli R and Hrelia P: Sulforaphane induces apoptosis in rhabdomyosarcoma and restores TRAIL-sensitivity in the aggressive alveolar subtype leading to tumor elimination in mice. Cancer Biol Ther 15: 1219-1225, 2014.

18 Cheng YM, Tsai CC and Hsu YC: Sulforaphane, a dietary isothiocyanate, induces $\mathrm{g}^{2} / \mathrm{m}$ arrest in cervical cancer cells through cyclin B1 downregulation and GADD45 $\beta / C D C 2$ association. Int J Mol Sci 17: E1530, 2016.

19 Tian H, Zhou Y, Yang G, Geng Y, Wu S, Hu Y, Lin K and Wu $\mathrm{W}$ : Sulforaphane-cysteine suppresses invasion via downregulation of galectin-1 in human prostate cancer DU145 and PC3 cells. Oncol Rep 36: 1361-1368, 2016.

20 Juengel E, Maxeiner S, Rutz J, Justin S, Roos F, Khoder W, Tsaur I, Nelson K, Bechstein WO, Haferkamp A and Blaheta RA: Sulforaphane inhibits proliferation and invasive activity of everolimus-resistant kidney cancer cells in vitro. Oncotarget 7: 85208-85219, 2016.

21 Juengel E, Euler S, Maxeiner S, Rutz J, Justin S, Roos F, Khoder W, Nelson K, Bechstein WO and Blaheta RA: Sulforaphane as an adjunctive to everolimus counteracts everolimus resistance in renal cancer cell lines. Phytomedicine 27: 1-7, 2017.

22 Zanichelli F, Capasso S, Cipollaro M, Pagnotta E, Cartenì M, Casale F, Iori R and Galderisi U: Dose-dependent effects of Rsulforaphane isothiocyanate on the biology of human mesenchymal stem cells, at dietary amounts, it promotes cell proliferation and reduces senescence and apoptosis, while at anti-cancer drug doses, it has a cytotoxic effect. Age (Dordr) 34: 281-293, 2012.

23 Herman-Antosiewicz A, Xiao H, Lew KL and Singh SV: Induction of p21 protein protects against sulforaphane-induced mitotic arrest in LNCaP human prostate cancer cell line. Mol Cancer Ther 6: 1673-1681, 2007.

24 Liu KC, Shih TY, Kuo CL, Ma YS, Yang JL, Wu PP, Huang YP, Lai KC and Chung JG: Sulforaphane induces cell death through $\mathrm{G}_{2} / \mathrm{M}$ phase arrest and triggers apoptosis in HCT 116 human colon cancer cells. Am J Chin Med 44: 1289-1310, 2016.
25 Juengel E, Kim D, Makarević J, Reiter M, Tsaur I, Bartsch G, Haferkamp A and Blaheta RA: Molecular analysis of sunitinib resistant renal cell carcinoma cells after sequential treatment with RAD001 (everolimus) or sorafenib. J Cell Mol Med 19: 430-441, 2015.

26 Juengel E, Dauselt A, Makarević J, Wiesner C, Tsaur I, Bartsch G, Haferkamp A and Blaheta RA: Acetylation of histone $\mathrm{H} 3$ prevents resistance development caused by chronic mTOR inhibition in renal cell carcinoma cells. Cancer Lett 324: 83-90, 2012.

27 Fan P, Zhang Y, Liu L, Zhao Z, Yin Y, Xiao X, Bauer N, Gladkich J, Mattern J, Gao C, Schemmer P, Gross W and Herr I: Continuous exposure of pancreatic cancer cells to dietary bioactive agents does not induce drug resistance unlike chemotherapy. Cell Death Dis 7: e2246, 2016.

28 Pappa G, Bartsch H and Gerhäuser C: Biphasic modulation of cell proliferation by sulforaphane at physiologically relevant exposure times in a human colon cancer cell line. Mol Nutr Food Res 51: 977-984, 2007.

29 Lubelska K, Wiktorska K, Mielczarek L, Milczarek M, Zbroińska-Bregisz I and Chilmonczyk Z: Sulforaphane regulates NFE2L2/Nrf2-dependent xenobiotic metabolism Phase II and Phase III enzymes differently in human colorectal cancer and untransformed epithelial colon cells. Nutr Cancer 68: 1338-1348, 2016.

30 Negrette-Guzmán M, Huerta-Yepez S, Vega MI, León-Contreras JC, Hernández-Pando R, Medina-Campos ON, Rodríguez E, Tapia E and Pedraza-Chaverri J: Sulforaphane induces differential modulation of mitochondrial biogenesis and dynamics innormal cells and tumor cells. Food Chem Toxicol 100: 90-102, 2017.

31 Hudecova S, Markova J, Simko V, Csaderova L, Stracina T, Sirova M, Fojtu M, Svastova E, Gronesova P, Pastorek M, Novakova M, Cholujova D, Kopacek J, Pastorekova S, Sedlak J and Krizanova O: Sulforaphane-induced apoptosis involves the type 1 IP3 receptor. Oncotarget 7: 61403-61418, 2016.

32 Heiss E and Gerhäuser C: Time-dependent modulation of thioredoxin reductase activity might contribute to sulforaphanemediated inhibition of NF-kappaB binding to DNA. Antioxid Redox Signal 7: 1601-1611, 2005.

33 Hydbring P, Castell A and Larsson LG: MYC Modulation around the CDK2/p27/SKP2 Axis. Genes (Basel) 8: E174, 2017.

34 Han SH, Chung JH, Kim J, Kim KS and Han YS: New role of human ribosomal protein S3: Regulation of cell cycle via phosphorylation by cyclin-dependent kinase 2. Oncol Lett 13 : 3681-3687, 2017.

35 Corlu A and Loyer P: Regulation of the $\mathrm{g} 1 / \mathrm{s}$ transition in hepatocytes: involvement of the cyclin-dependent kinase cdk1 in the DNA replication. Int J Hepatol 2012: 689324, 2012.

$36 \mathrm{Fu}$ XJ, Li HX, Yang K, Chen D and Tang H: The important tumor suppressor role of PER1 in regulating the cyclin-CDKCKI network in SCC15 human oral squamous cell carcinoma cells. Onco Targets Ther 9: 2237-2245, 2016.

37 Kosakowska-Cholody T, Cholody WM, Hariprakasha HK, Monks A, Kar S, Wang M, Michejda CJ and Carr BI: Growth inhibition of hepatocellular carcinoma cells in vitro and in vivo by the 8-methoxy analog of WMC79. Cancer Chemother Pharmacol 63: 769-778, 2009.

38 Wu J, Song T, Liu S, Li X, Li G and Xu J: Icariside II inhibits cell proliferation and induces cell cycle arrest through the ROSp38-p53 signaling pathway in A375 human melanoma cells. Mol Med Rep 11: 410-416, 2015. 
39 Relja B, Meder F, Wilhelm K, Henrich D, Marzi I and Lehnert M: Simvastatin inhibits cell growth and induces apoptosis and $\mathrm{G}_{0} / \mathrm{G}_{1}$ cell cycle arrest in hepatic cancer cells. Int J Mol Med 26: 735-741, 2010

40 Kang YJ, Park KK, Chung WY, Hwang JK and Lee SK: Xanthorrhizol, a natural sesquiterpenoid, induces apoptosis and growth arrest in HCT116 human colon cancer cells. J Pharmacol Sci 111: 276-284, 2009.

41 Seo YS, Kang OH, Kong R, Zhou T, Kim SA, Ryu S, Kim HR and Kwon DY: Polygalacin D induces apoptosis and cell cycle arrest via the PI3K/Akt pathway in non-small cell lung cancer. Oncol Rep 39: 1702-1710, 2018.

42 Chen S, Dong S, Li Z, Guo X, Zhang N, Yu B and Sun Y: Atorvastatin Calcium Inhibits PDGF- $\beta \beta$-Induced Proliferation and Migration of VSMCs Through the G0/G1 Cell Cycle Arrest and Suppression of Activated PDGFR $\beta$-PI3K-Akt Signaling Cascade. Cell Physiol Biochem 44: 215-228, 2017.

43 Chen KC, Yang TY, Wu CC, Cheng CC, Hsu SL, Hung HW, Chen JW and Chang GC: Pemetrexed induces S-phase arrest and apoptosis via a deregulated activation of Akt signaling pathway. PLoS One 9: e97888, 2014.
44 Mukhopadhyay P, Ali MA, Nandi A, Carreon P, Choy H and Saha D: The cyclin-dependent kinase 2 inhibitor down-regulates interleukin-1beta-mediated induction of cyclooxygenase-2 expression in human lung carcinoma cells. Cancer Res 66: 17581766, 2006.

45 Zhou JX, Fan LX, Li X, Calvet JP and Li X: TNFa signaling regulates cystic epithelial cell proliferation through Akt/mTOR and ERK/MAPK/Cdk2 mediated Id2 signaling. PLoS One 10: e0131043, 2015.

46 Maddika S, Ande SR, Wiechec E, Hansen LL, Wesselborg S and Los M: Akt-mediated phosphorylation of CDK2 regulates its dual role in cell cycle progression and apoptosis. J Cell Sci 121: 979-988, 2008.

47 Dacosta C and Bao Y: The role of MicroRNAs in the chemopreventive activity of sulforaphane from cruciferous vegetables. Nutrients 9: E902, 2017.

Received October 10, 2018

Revised October 23, 2018

Accepted October 24, 2018 